\title{
Phytoplankton on the western coasts of Baja California in two different seasons in 1998
}

\author{
DAVID U. HERNÁNDEZ-BECERRIL, ERNESTO BRAVO-SIERRA \\ and JOSÉ A. AKÉ-CASTILLO \\ Laboratorio de Diversidad y Ecología del Fitoplancton Marino, Instituto de Ciencias del Mar y Limnología, Universidad \\ Nacional Autónoma de México (UNAM), Apdo. postal 70-305, México, D.F. 04510 México. \\ E-mail: dhernand@mar.icmyl.unam.mx
}

\begin{abstract}
SUMMARY: Phytoplankton was studied in two different seasons of 1998 (March-April and December), during two cruises along the western coasts of Baja California, in three zones. Two different protocols for obtaining and studying phytoplankton were followed. In the March-April season, phytoplankton had relatively low species richness and was dominated in cell density (up to 93\%) by coccolithophorids (mainly Emiliania huxleyi), together with nanoplanktonic centric and pennate diatoms, with abundances ranging from $5.410^{3}$ to $1.210^{5}$ cells L$^{-1}$. In December, phytoplankton had higher species richness and was represented by larger, chain-forming diatom species, such as Pseudonitzschia delicatissima and P.pungens, which were widespread and numerically significant. There was a relative scarcity of coccolithophorids and thecate dinoflagellates, and densities were between $710^{2}$ and $1.410^{6}$ cells L $^{-1}$. Hydrographic and oceanographic conditions in March-April were influenced by the occurrence of El Niño and the phytoplankton structure was found to be modified accordingly, with nanoplanktonic coccolithophorids and diatoms being significant contributors to the total abundance. In contrast, postupwelling conditions might have favoured relatively high densities of Pseudonitzschia and other diatoms in December, 1998. Coccolithophorids have not been previously regarded as important contributors to the phytoplankton abundances in Baja California.
\end{abstract}

Keywords: Baja California, coccolithophorids, diatoms, El Niño, phytoplankton.

RESUMEN: Fitoplancton en Costas occidentales de Baja California en dos temporadas distintas de 1998. - Se estudió el fitoplancton en dos temporadas diferentes de 1998 (marzo-abril y diciembre), durante dos cruceros en tres zonas de las costas de Baja California. Se siguieron dos protocolos distintos para obtener y estudiar el fitoplancton. En marzo-abril, el fitoplancton tuvo una riqueza de especies baja y estuvo dominado en densidades celulares (de hasta 93\%) por cocolitofóridos (principalmente Emiliania huxleyi), junto con diatomeas centrales y pennales nanoplanctónicas, con abundancias desde $5.410^{3}$ a $1.210^{5}$ céls $\mathrm{L}^{-1}$. Para diciembre, el fitoplancton incrementó la riqueza de especies y estuvo representado por diatomeas más grandes, formadoras de cadenas, que se distribuyeron ampliamente y fueron numéricamente importantes, como: Pseudonitzschia delicatissima y $P$. pungens, con relativa escasez de cocolitofóridos y dinoflagelados tecados, con densidades entre $710^{2}$ y $1.410^{6}$ céls $\mathrm{L}^{-1}$. Las condiciones oceanográficas en marzo-abril indicaron la presencia de El Niño y los resultados mostraron una estructura de fitoplancton modificada por ello, con una contribución importante de cocolitofóridos y diatomeas nanoplanctónicas a la abundancia total. En cambio, en diciembre, las condiciones de post-surgencia pudieron haber favorecido las relativas altas densidades de especies de Pseudonitzschia y otras diatomeas. Los cocolitofóridos no habían sido documentados previamente como contribuyentes importantes a la abundancia fitoplanctónica en Baja California.

Palabras clave: Baja California, cocolitofóridos, diatomeas, El Niño, fitoplancton.

\section{INTRODUCTION}

The western coastal area of Baja California, Mexico has traditionally been considered a very rich and productive system, in which the influence of the California Current is remarkable (Parrés Sierra et al., 1997) and upwellings play an important role in keeping this high productivity 
(Longhurst et al., 1967; Wang and Walsh, 1976; Parrés Sierra et al., 1997). The phytoplankton of this area have been relatively well-studied: there are studies on composition, distribution, primary productivity and variability of some of its features, as well as the main factors controlling the natural variation of phytoplankton (Smayda, 1975; Estrada and Blasco, 1979; Hernández-Becerril, 1985; Cardona et al., 1990; Millán-Núñez and Loya Salinas, 1993; Cohen Fernández, 2000).

Diatoms and "armoured" dinoflagellates have been studied in greater detail than other taxonomic groups and they are usually regarded as the dominant phytoplankton in the area (Allen, 1923, 1924, 1934; Balech, 1960), and more recently (Hernández-Becerril, 1988, 1989, 1995, 1998; Hernández-Becerril and Tapia, 1995). Other groups (e.g. coccolithophorids and other flagellates) or size fractions (e.g. nanoplankton and picoplankton) have not been recognized as important contributors to the diversity, biomass and primary productivity. In nearby locations, in the California current system, coccolithophorids and other flagellates have been identified and counted (in terms of cell numbers and cellular volume) (Reid et al., 1970), the relative importance of microplankton (netplankton) and nanoplankton has been stressed (Malone, 1971; Mullin, 1998), and the contribution to biomass and productivity of fractions of phytoplankton (smaller and larger than $8 \mu \mathrm{m}$ ) in a coastal area off Baja California has been studied (González Morales and GaxiolaCastro, 1991).

The El Niño 1997-1998 event caused a pronounced effect on the climate, the hydrographic and oceanographic conditions, and the biological communities of the Pacific Ocean (Lynn et al., 1998; Hayward et al., 1999). This event reached a second peak of intensity in early 1998 and relaxed considerably by the middle of 1998. By the end of 1998 it disappeared completely from Baja California waters (Lavaniegos et al., 2002), giving way to the strong La Niña event (Hayward et al., 1999).

In this paper, results of the structure of the phytoplankton (in terms of species composition, abundance and distribution) collected during two cruises along the western coasts of Baja California, in two different seasons of 1998, one under the influence of El Niño and the other in contrasting conditions, are presented and discussed.

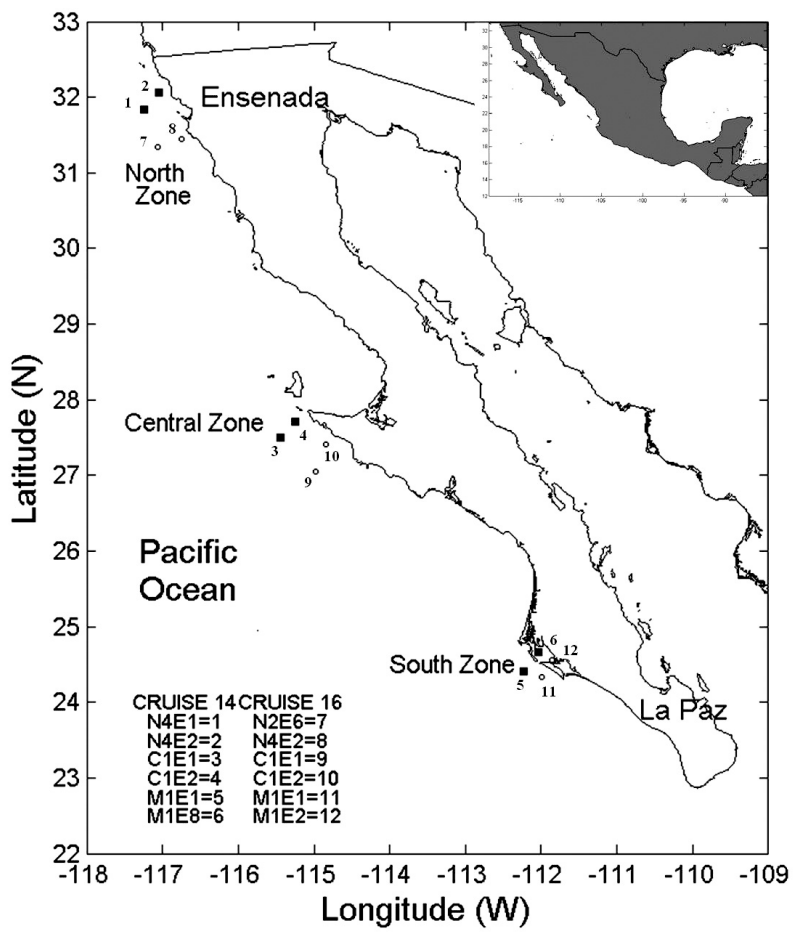

FIG. 1. - Map of the study area, showing sampling station during two cruises: Stations 1-6 from the cruise SIMSUP 14 (March-April, 1998), Stations 7-12 from the cruise SIMSUP 16 (December, 1998).

\section{MATERIAL AND METHODS}

Sampling for this study was carried out during two cruises, on board "El Puma": SIMSUP XIV (March-April, 1998) and SIMSUP XVI (December, 1998), along the western coasts of Baja California, Mexico, in three different zones (north, centre and south) (Fig. 1). Samples were taken basically following two distinct protocols: (1) In March-April, 1998, which is considered the decline of the El Niño 1997-1998 event, phytoplankton was collected with a Niskin bottle (usually $4 \mathrm{~L}$ ) from three depths at 6 fixed stations (two in the three different zones) and filtered through Millipore $0.45 \mu \mathrm{m}$ meshed-filters with a vacuum pump (less than $100 \mathrm{~mm} \mathrm{Hg}$ ). The filters were immediately rinsed with a buffered $(\mathrm{pH}$ 7.5-8) solution, air dried at room temperature, and then stored in plastic Petri dishes (Winter et al., 1999; Bollmann et al., 2002). (2) In December, 1998, phytoplankton was taken with a Niskin bottle (4 L) from three depths at 14 fixed stations. Approximately $250 \mathrm{ml}$ was then fixed with Lugol's solutions and placed in dark bottles until analysis. Variables measured in both cruises were obtained by a CTD instrument, including temperature, salinity and dissolved oxygen (vertical profiles). 
Phytoplankton was analyzed with protocol 1 as follows: small pieces (approximately $1 \mathrm{~cm}^{2}$ ) of the filters containing phytoplankton were cut then mounted onto slides. An oil immersion was added to clear the filters, then they were covered by a coverslip and observed with a light microscope (LM), using bright field and total magnifications of $600 \times$ or $1250 \times$, to count and confirm species identification respectively (Bollmann et al., 2002, in most details, except the use of immersion oil and the bright field microscopic technique). Preliminary species identification and cell counting were made in LM. The number of cells per litre was estimated from data such as the number of organisms counted, areas of counting and filter, and volume filtered (Bollmann et al., 2002). Observations were also made by scanning electron microscopy (SEM) to confirm identification of tiny species, using small pieces of filters treated conventionally for SEM. Very few cells were found to be collapsed (due to the possible effect of changing $\mathrm{pH}$ or vacuum pressure). Samples fixed with Lugol's solution (protocol 2) were studied using an inverted microscope, following the usual settling in chambers and routine counting procedures (Hasle, 1978).

We used two different protocols to study the phytoplankton in this study, which may prevent direct comparisons being made between different seasons (March-April, 1998 and December, 1998). Our basic purpose when filtering samples (protocol 1) was to obtain the preservable fraction of the phytoplankton, especially the coccolithophorids, although the filters also contained diatoms, thecate (and resistant naked) dinoflagellates, silicoflagellates and other groups which have siliceous or carbonate coverings. This method underestimates the contribution of fragile "phytoflagellates", such as forms of Prasinophyceae, Cryptophytes, other Haptophytes, and also some picoplanktonic forms.

The number of coccolithophorids is estimated more accurately using this method (Bollmann et al., 2002), as we can confirm identification and counting by SEM. Therefore, we were able to establish a phytoplankton community dominated by this group, and the diatoms, the group considered the most significant in terms of species diversity, abundance, and biomass in the study area, are not excluded by this method.

Samples taken and studied following the method for inverted microscope were analyzed very soon after collection, which prevents a possible dissolu- tion of coccoliths from coccolithophorids. Hence, we were able to count this group when analyzing samples. Observation of other flagellates and nanoplanktonic diatoms (i.e. Chrysochromulina sp., Fragilariopsis pseudonana, Meringosphaera mediterranea, Myrionecta rubra, Nitzschia bicapitata) following this protocol allowed us to be confident with the phytoplankton composition and estimated abundances.

\section{RESULTS}

\section{Hydrographic conditions and phytoplankton, March-April, 1998}

Surface temperature data for March-April, 1998, were higher (by more than $1^{\circ} \mathrm{C}$ ) than those usually reported in other studies for this season (Lynn et al., 1998). The thermocline in most stations was located between 50 and $60 \mathrm{~m}$, except in a shallow station (Fig. 2). There was only a significant change in salinity in a station situated in Bahia Magdalena (M1 E8), and in the remaining stations it did not change considerably (Fig. 2). Dissolved oxygen showed variation similar to temperature (Fig. 2).

The phytoplankton showed low species diversity, with up to 82 species identified. Its composition exhibited a community predominated by nanoplanktonic forms, in which coccolithophorids were important contributors to the abundance, mainly the species Emiliania huxleyi and Gephyrocapsa oceanica (Table 1). Diatoms were represented by smallsized, solitary and lanceolate/centric species, some of them of tropical affinity such as Asteromphalus sarcophagus, Fragilariopsis pseudonana, Nitzschia bicapitata and some Thalassiosira species, which were numerically significant. A few diatoms of fresh-water/brackish habitats also occurred in some samples. Thecate dinoflagellates appeared to be rather scarce, whereas the numbers of "naked"/unarmoured dinoflagellates were slightly higher. The heterotrophic flagellate Meringosphaera mediterranea was a very common, widespread species, and silicoflagellates were very common too, although not abundant.

The abundances of phytoplankton were low to relatively high, ranging between $5.410^{3}$ and $1.210^{5}$ cells $\mathrm{L}^{-1}$, with the coccolithophorids making up to a maximum of $93 \%$ of the total abundance (Table 2), and in some points reaching a ratio of 21:1 with 

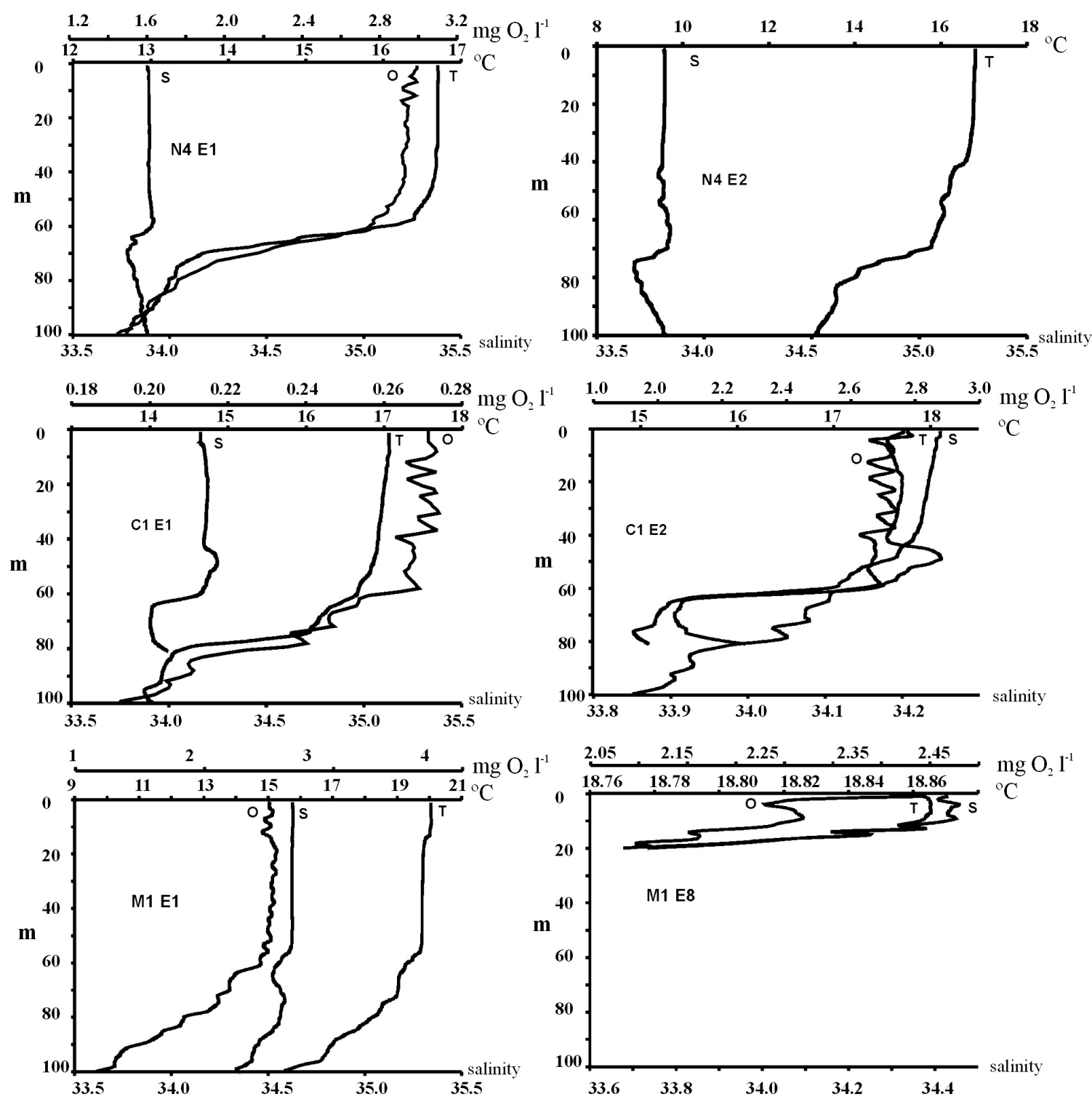

FIG. 2. - Vertical profiles of temperature, salinity and dissolved oxygen at stations from the cruise SIMSUP 14 (March-April, 1998).

regard to diatoms. These abundances were rather homogeneous (about the same magnitude order) with respect to both horizontal and vertical distribution of phytoplankton in most stations, except C1 E1 (zone centre), where we found the maximum values of phytoplankton abundances at the surface and subsurface, with a high contribution from the coccolithophorids (1.1 $10^{5}$ and $0.9510^{5}$ cells L ${ }^{-1}$ respectively) (Table 2 ).

\section{Hydrographic conditions and phytoplankton, December, 1998}

Surface temperatures were usual for this time of the year. Well-defined thermoclines were only detected at stations of the northern and central zones. They were not found below $45 \mathrm{~m}$ (Fig. 3). Salinity showed no considerable variation (not even in a station at Bahia Magdalena, M1 E2), and dissolved oxygen again varied in parallel to temperature, except in station N2 E6 (Fig. 3).

The number of species in the phytoplankton was relatively higher than in the precedent season, with up to 121 species identified, with somewhat homogeneous communities containing large- and medium-sized chain forming diatoms. Two species, Pseudonitzschia delicatissima and P. pungens were widespread and significant contributors to the total phytoplankton abundance (Table 1). Other traditionally common diatoms, such as species of Chaetoceros were not as abundant as in other sea- 
TABLE 1. - Dominant species in cell densities during March-April, 1998, and December, 1998 respectively.

\begin{tabular}{|c|c|c|}
\hline Maxim & $\begin{array}{l}\text { density } \\
\text { cells } L^{-1} \text { ) }\end{array}$ & Mean \\
\hline \multicolumn{3}{|l|}{ MARCH-APRIL, 1998} \\
\hline Emiliania huxleyi & 73000 & 22036 \\
\hline Gephyrocapsa oceanica & 35200 & 9344 \\
\hline Nitzschia bicapitata & 2500 & 980 \\
\hline Fragilariopsis pseudonana & 1420 & 640 \\
\hline Syracosphaera pulchra & 1230 & 560 \\
\hline Thalassiosira oestrupi var. venrickae & 820 & 230 \\
\hline \multicolumn{3}{|l|}{ Total number of species: 82} \\
\hline \multicolumn{3}{|l|}{ DECEMBER, 1998} \\
\hline Pseudonitzschia delicatissima & 114681 & 14071 \\
\hline Pseudonitzschia pungens & 95567 & 8107 \\
\hline Chaetoceros curvisetus & 99815 & 7056 \\
\hline Guinardia delicatula & 165650 & 6917 \\
\hline Guinardia striata & 116804 & 6454 \\
\hline Detonula pumila & 146536 & 5972 \\
\hline Chaetoceros lorenzianus & 82825 & 5037 \\
\hline Chaetoceros debilis & 110433 & 4591 \\
\hline Chaetoceros compressus & 114681 & 3911 \\
\hline Chaetoceros laciniosus & 46722 & 2481 \\
\hline Chaetoceros brevis & 31416 & 2327 \\
\hline Eucampia cornuta & 29732 & 1673 \\
\hline Skeletonema cf. costatum & 31856 & 1616 \\
\hline Chaetoceros radicans & 35343 & 1464 \\
\hline Chaetoceros tortissimus & 26546 & 1242 \\
\hline Dactilyosolen fragilissimus & 27915 & 1119 \\
\hline Prorocentrum triestinum & 11781 & 1158 \\
\hline Nitzschia bicapitata & 23562 & 983 \\
\hline Guinardia flaccida & 24313 & 983 \\
\hline Ceratium furca & 1815 & 84 \\
\hline Prorocentrum micans & 1062 & 25 \\
\hline Ceratium fusus & 708 & 16 \\
\hline \multicolumn{3}{|l|}{ Total number of species: 121} \\
\hline
\end{tabular}

sons, and species of Rhizosolenia and Thalassiosira only appeared sporadically. Flagellates were rather scarce (including coccolithophorids and thecate dinoflagellates).

Phytoplankton abundances varied notably, from $710^{2}$ to $1.410^{6}$ cells L $^{-1}$, with the lowest abundances in the northern and central zones and the highest ones at the surface layer in the southern zone (Bahia Magdalena and surroundings), where the maximum density reached more than a million cells $\mathrm{L}^{-1}$ (Table 2). Generally, phytoplankton cell numbers were higher in surface and subsurface waters (up to $50 \mathrm{~m}$ ) (Table 2).

\section{DISCUSSION}

\section{Hydrographic and oceanographic conditions: the El Niño effect}

Available data (either obtained from the field, Fig. 2, or from other sources, e.g. Lynn et al., 1998; Hayward et al., 1999; Lavaniegos et al., 2002) sup-
TABLE 2. - Phytoplankton abundances (cells $\mathrm{L}^{-1}$ ) in March-April, 1998, and December, 1998, with dominance (\%) of coccolithophorids (Emiliania huxleyi and Gephyrocapsa oceanica) and Pseudonitzschia species respectively. Stations as in Figure 1.

MARCH-APRIL, 1998

\begin{tabular}{|c|c|c|c|c|c|}
\hline \multicolumn{3}{|c|}{ Station N4E1 } & \multicolumn{3}{|c|}{ Station N4E2 } \\
\hline $5 \mathrm{~m}$ & 54749 & & $5 \mathrm{~m}$ & 50643 & \\
\hline $30 \mathrm{~m}$ & 56118 & & $30 \mathrm{~m}$ & 71995 & $88 \%$ \\
\hline $50 \mathrm{~m}$ & 57760 & $87 \%$ & $50 \mathrm{~m}$ & 62120 & $93 \%$ \\
\hline \multicolumn{3}{|c|}{ Station C1E1 } & \multicolumn{3}{|c|}{ Station C1E2 } \\
\hline $5 \mathrm{~m}$ & 126744 & \multirow{3}{*}{$\begin{array}{l}87 \% \\
91 \%\end{array}$} & $5 \mathrm{~m}$ & 6296 & \\
\hline $30 \mathrm{~m}$ & 105666 & & $30 \mathrm{~m}$ & 5475 & \\
\hline $50 \mathrm{~m}$ & 20257 & & $50 \mathrm{~m}$ & 7938 & \\
\hline \multicolumn{3}{|c|}{ Station M1E1 } & \multicolumn{3}{|c|}{ Station M1E8 } \\
\hline $5 \mathrm{~m}$ & 20530 & \multirow{3}{*}{$88 \%$} & $5 \mathrm{~m}$ & 13961 & \\
\hline $30 \mathrm{~m}$ & 20257 & & $10 \mathrm{~m}$ & 9857 & \\
\hline $50 \mathrm{~m}$ & 20530 & & $15 \mathrm{~m}$ & 16972 & \\
\hline
\end{tabular}

DECEMBER, 1998

\begin{tabular}{lrlr}
\hline \multicolumn{2}{l}{ Station N2E6 } & \multicolumn{2}{l}{ Station N2E8 } \\
$5 \mathrm{~m}$ & 53233 & $5 \mathrm{~m}$ & 4720 \\
$25 \mathrm{~m}$ & 36216 & $25 \mathrm{~m}$ & 43733
\end{tabular}

$\begin{array}{llll}25 \mathrm{~m} & 36216 & 25 \mathrm{~m} & 43733 \\ 52 \mathrm{~m} & 56632 & 50 \mathrm{~m} & 13686\end{array}$

Station C1E1

$5 \mathrm{~m} \quad 84430$

$50 \mathrm{~m} \quad 1745$

$5 \mathrm{~m} \quad 7854$

$50 \mathrm{~m} \quad 79639$

Station M1E1

$5 \mathrm{~m} \quad 320050$

$50 \mathrm{~m} \quad 675442$

$80 \mathrm{~m} \quad 152908$

$\begin{array}{lll}50 \mathrm{~m} & 79639 & \\ 100 \mathrm{~m} & 11892 & 53 \%\end{array}$

Station M1E2

$5 \mathrm{~m} \quad 1414395$

$17 \mathrm{~m} \quad 642049$

port the general condition: El Niño was occurring in Baja California waters at the time that collections were made for March-April, 1998. The temperature profiles showed that the thermocline was relatively deep (up to 50-60 m), with the sub-surface and surface water being relatively homogeneous (Fig. 2). Temperatures of the sub-surface and surface water were slightly higher than the general average for this time in the study area. Chlorophyll $a$ data for January-February, 1998, showed an increase in surface concentration and a strong gradient onshoreoffshore, with higher values in the coastal zone. Whereas by summer and autumn, 1998 (July, September-October respectively), chlorophyll $a$ concentrations were significantly lower (Lavaniegos et al., 2002, 2003).

We consider that these conditions had a strong influence on the phytoplankton community and were the reason for the composition of the phytoplankton with a strong numerical dominance of nanoplanktonic forms, especially coccolithophorids and small-sized diatoms with similar abundances from surface to $50 \mathrm{~m}$. 
740 • D.U. HERNÁNDEZ-BECERRIL et al.
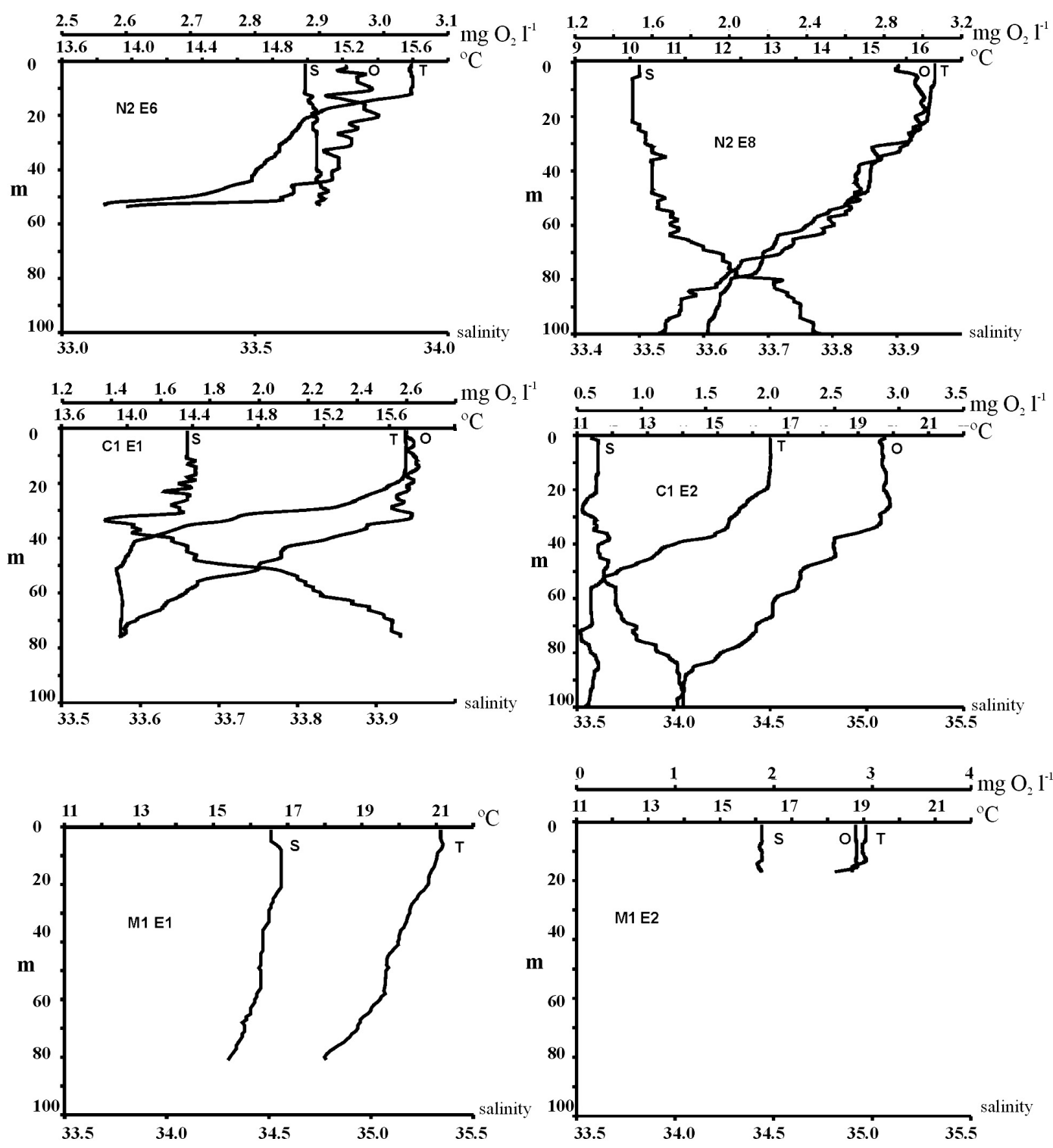

FIG. 3. - Vertical profiles of temperature, salinity and dissolved oxygen at stations from the cruise SIMSUP 16 (December, 1998).

After a period of weaker than normal upwelling through late spring and summer 1998 from San Francisco to southern Baja California, the positive index anomaly indicates slightly above normal upwelling in late 1998 and early 1999 (Hayward et al., 1999). In fact, typical colder surface waters associated with upwelling in coasts off Baja California were observed during October 1998 (Aguirre-Hernández et al., 2004). Our hydrographic data also support these observations, indicating upwellings still occurring during December 1998, with post-upwelling conditions at different zones throughout the study area (Fig. 3). These circumstances may have favoured the spread and relatively high abundances of certain diatom species, such as
Pseudonitzschia delicatissima and P. pungens, in December, 1998. A closely related species, Pseudonitzschia australis, exhibited high abundances in Southern California from February to August, even forming blooms by March, 1991 (Lange et al., 1994). This has been associated with the intrusion of cool, nutrient-rich waters, which are a product of upwellings (Lange et al., 1994).

The extensive spread of the Pseudonitzschia species was evident from May, 1998 on the western coasts of the USA, such as Washington (Adams et al., 2000; Horner et al., 2000) and California, especially by July, 1998 (Bargu and Silver, 2003), including some cases of intoxication in Californian waters due to blooms of some toxic species (Trainer 

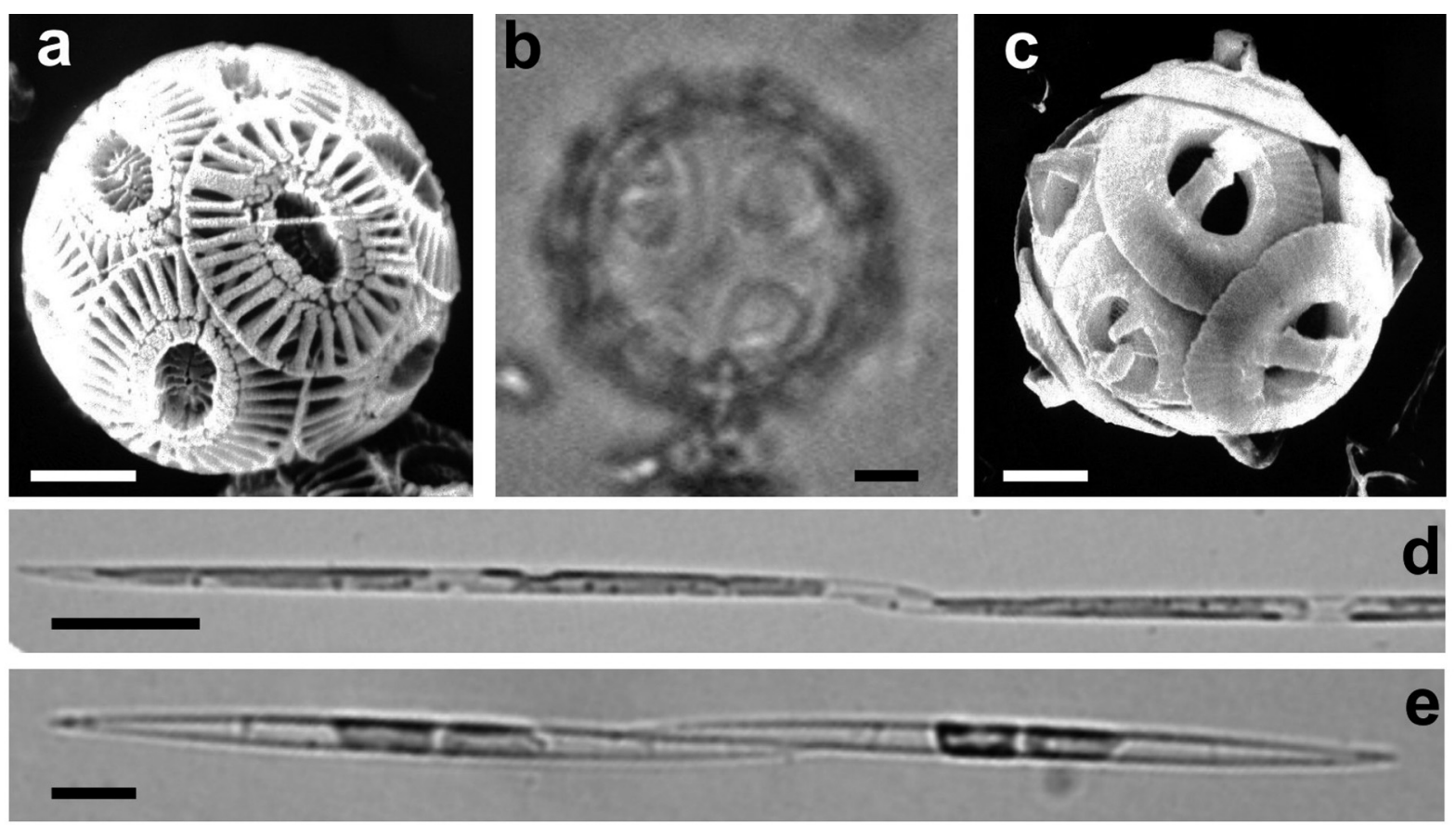

FIG. 4. - Important species during March-April and December, 1998; a, the coccolithophorid Emiliania huxleyi, SEM; b, c, Gephyrocapsa oceanica, another coccolithophorid, LM and SEM respectively; d, e, the chain-forming, pennate diatoms Pseudonitzschia delicatissima and $P$. pungens respectively, LM. Scale bars $=10 \mu \mathrm{m}(\mathrm{d}, \mathrm{e})$ and $2 \mu \mathrm{m}(\mathrm{a}-\mathrm{c})$.

et al., 2000, 2001). This distribution was also documented in more tropical waters from the Mexican Pacific from November, 1998, until April, 1999, from Baja California to warmer waters around Mazatlán, México (Gómez-Aguirre, 1999; Meave et $a l .$, 2000). This large-scale distribution may be explained in terms of local events (for instance postupwellings and heavy precipitations, among others), but also on a larger meteorological and oceanographic scale as the effect of La Niña.

\section{Phytoplankton structure}

In our results from March-April, 1998, the coccolithophorid Emiliania huxleyi (Fig. 4a) was the most significant contributor to the cell abundance of phytoplankton, although it did not reach spectacular densities (less than $1.210^{5}$ cells $\mathrm{L}^{-1}$ ) or produce real blooms (as documented by Tyrell and Merico, 2004, in other parts of the world) (Tables 1 and 2). It was usually found together with Gephyrocapsa oceanica (Fig. 4b, c), which occurred in lower abundances (Table 1). Emiliania huxleyi appears as the species involved in most blooms of coccolithophorids world-wide and it is considered cosmopolitan (Tyrell and Merico, 2004). Some recent studies show that this species has high genetic variability, possibly with different physiological responses to different oceanographic conditions (Brand, 1982; Young and Westbroek, 1991; Medlin et al., 1994).

Coccolithophorids are usually regarded as an important and abundant phytoplankton group in warm, stratified and oligotrophic waters (Brand, 1994). They often bloom in many areas, including coastal areas. They also reach high populations in mature upwelled waters (Balch, 2004). However, no previous report has been made on numerical dominance of coccolithophorids in the phytoplankton of Baja California, although a paper dealing with the floristic of this group in the same study area was recently published (Hernández-Becerril et al., 2001), and previous plankton studies in La Jolla, California, USA, included coccolithophorids (with a maximum Emiliania huxleyi abundance of $510^{5}$ cells L ${ }^{-1}$, in August, 1967, Reid et al., 1970).

Nanoflagellates and naked dinoflagellates yielded considerable densities only at the surface, in the northern and central zones of Baja California in autumn and winter, 1998, in a previous plankton study during different seasons between September, 1997 and October, 1998, whereas centric diatoms were only abundant in autumn, 1997 (Lavaniegos et al., 2003). This information is consistent with our results.

Diatoms have traditionally been regarded as the most significant group in the study area, as they are 
usually dominant in these upwelling regions. The relative scarcity of this group in the March-April season and the presence and relative abundance of some rather unusual species in the study area, such as the diatom Asteromphalus sarcophagus, which is considered to be a tropical form, confirm the intrusion of warmer water into the system. Furthermore, the association of diatoms in the tropical-subtropical species complex Nitzschia bicapitata/N. bifurcata (both species were found in this season) has been previously recognized in Pacific waters (Lee and Fryxell, 1996; Fryxell, 2000).

Other evidence of changing oceanographic conditions and their effects on phytoplankton comes from micropaleontologists: terrigenous input into Santa Barbara Basin, California, USA, was significantly higher during El Niño 1997-1998, which reflects higher rainfall and runoff into the basin (Lange et al., 2000). Diatom fluxes were an order of magnitude lower than in the 1996 non-El Niño period, the proportion of warm water flora increased significantly, and by winter of 1998 organic carbon fluxes were unusually high (perhaps indicating the significant populations of coccolithophorids) (Lange et al., 2000). We also found indicators of a freshwater influence, such as the diatom Cocconeis placentula, in very low numbers.

In conclusion, the phytoplankton community found for March-April, 1998 along the coasts of Baja California was different to the usual community there, and reflects the particular conditions of El Niño 1997-1998. The usual composition of the phytoplankton for April in the system of Baja California/California is rich in diatoms. The community detected for December, 1998 is more typical and reflects more periodical environmental conditions. Our results of this season (concentrated in Table 1) are very similar to those provided by Venrick (1998) in her study of phytoplankton from a neighbouring area (southern California) in April 1993 and 1995, with similar significant species (within the maximum rank) such as the diatoms Pseudonitzschia spp. (Figs 4d, e), Chaetoceros compressus, C. debilis, C. radicans and Skeletonema costatum.

However, despite the structure of the phytoplankton community (composition, abundance and distribution) being different in the two periods studied on Baja Californian coasts, other ecological parameters seemed to remain the same during El Niño 1997-1998 in California, USA, such as the general relation between biomass of large phytoplankton and the depth of the nitricline (Mullin, 2000).

\section{ACKNOWLEDGEMENTS}

Many thanks are due to Drs C. Robinson and V. Arenas for their invitation to the cruises SIMSUP XIV and XVI and the "El Puma" crew for their support during the cruises. Y. Hornelas O. gave skilled assistance for SEM. Partial financial support (to JAA-C) was provided by DGAPA (PAPIIT), UNAM, Project No. IN210596.

\section{REFERENCES}

Adams, N.G., M. Lesoing and V.L. Trainer. - 2000. Environmental condition associated with domoic acid in razor clams on the Washington coast. J. Shellfish Res., 19: 1007-1015.

Aguirre-Hernández, E., G. Gaxiola-Castro, S. Nájera-Martínez, T. Baumgartner, M. Kahru and B.G. Mitchell. - 2004. Phytoplankton absorption, photosynthesis parameters, and primary production off Baja California: summer and autumn 1998. Deep-Sea Res. II, 51: 799-816.

Allen, W.E. - 1923. Observations on surface distribution of marine plankton diatoms of Lower California in 1921. Proc. Calif. Acad. Sci., 12: 438-442.

Allen, W.E. - 1924. Observations on surface distribution of marine plankton diatoms of Lower California in 1922. Ecology, 5: 389-392.

Allen, W.E. - 1934. Marine plankton diatoms of lower California in 1931. Bot. Gaz., 95: 485-492.

Balch, W.M. - 2004. Re-evaluation of the physiological ecology of coccolithophores. In: H.R. Thierstein and J.R. Young (eds.), Coccolithophores. From Molecular Processes to Global Impact, pp. 165-190. Springer-Verlag, Berlin.

Balech, E. - 1960. The changes in the phytoplankton population off the California coast. Cal. Coop. Ocean. Fish. Inv.Rep., 7: 127-132.

Bargu, S., M.W. Silver. - 2003. Field evidence of krill grazing on the toxic diatom genus Pseudo-nitzschia in Monterey Bay, California. Bull. Mar. Sci., 72: 629-638.

Bollmann, J., M.Y. Cortés, A.T. Haidar, B. Brabec, A. Close, R. Hofmann, S. Palma, L. Tupas and H.R. Thierstein. - 2002. Techniques for quantitative analyses of calcareous marine phytoplankton. Mar. Micropaleontol., 44: 163-185.

Brand, L.E. - 1982. Genetic varibility and spatial patterns of genetic differentiation in the reproductive rates of the marine coccolithophorids Emiliania huxleyi and Gephyrocapsa oceanica. Limnol. Oceanog., 27: 236-245.

Brand, L.E. - 1994. Physiological ecology of marine coccolithophores. In: Winter, A. and W.G Siesser (eds.), Coccolithophores. pp. 39-49. Cambridge Univ. Press, New York.

Cardona Canizales, C., R. Millán-Núñez, J.R. Lara-Lara and J.E. Valdez-Holguín. - 1990. Variabilidad espacio temporal de la clorofila $a$ en una zona de surgencia frente a Baja California. Cienc. Mar., 16: 53-65.

Cohen Fernández, E.J. - 2000. Estructura y dinámica de la comunidad de fitoplancton en la boca de Bahía Magdalena, costa occidental de Baja California Sur, México. M. Sc. Thesis. Fac. Ciencias, UNAM, México.

Estrada, M. and D. Blasco. - 1979. Two phases of the phytoplankton community in the Baja California upwelling. Limnol. Oceanogr., 24: 1065-1080.

Fryxell, G.A. - 2000. Nitzschia bicapitata (Bacillariophyceae) and related taxa from oceanic aggregations. Diatom Res., 15: 43-73. 
Gómez-Aguirre, S. - 1999. Florecimientos de fitoplancton invernal (1998-1999) en el NW de México. Abstracts X Meeting of the Mexican Society of Planctology and III International Meeting of Planctology. Mazatlán, Sinaloa, México, 28-30 April, 1999.

González Morales, A.T. and G. Gaxiola-Castro. - 1991. Variación día a día de características fisico-químicas, biomasa y productividad primaria del fitoplancton en una zona de surgencia costera de Baja California. Cienc. Mar., 17: 21-37.

Hasle, G.R. - 1978. Using the inverted microscope. In: Sournia, A (ed.), Phytoplankton Manual. pp. 191-196. UNESCO, Paris.

Hayward, T.L., T.R. Baumgartner, D.M. Checkley, R. Durazo, G Gaxiola-Castro, K.D. Hyrenbach, A.W. Mantyla, M.M. Mullin, T. Murpheree, F.B. Schwing, P.E. Smith and M.J. Tegner. 1999. The state of the California Current, 1998-1999: transition to cool-water conditions. Cal. Coop. Ocean. Fish. Inv. Rep., 40: 29-62.

Hernández-Becerril, D.U. - 1985. Abundancia y distribución del fitoplancton entre Punta Blanca y Punta Rosarito, B.C. en el verano de 1980. Inv. Mar. CICIMAR, 2: 59-69.

Hernández-Becerril, D.U. - 1988. Planktonic dinoflagellates (except Ceratium and Protoperidinium) from the Gulf of California and off the coasts of Baja California. Bot. Mar., 31: 423-435.

Hernández-Becerril, D.U. - 1989. Species of the dinoflagellate genus Ceratium (Dinophyceae) from the Gulf of California and coasts off Baja California, Mexico. Nova Hedw., 48: 33-54.

Hernández-Becerril, D.U. - 1995. Planktonic diatoms from the Gulf of California and coasts off Baja California: the genera Rhizosolenia, Proboscia, Pseudosolenia, and former Rhizosolenia species. Diatom Res., 10: 251-267.

Hernández-Becerril, D.U. - 1998. Species of the planktonic diatom Pseudo-nitzschia of the Pacific coasts of Mexico. Hydrobiologia, 379: 77-84.

Hernández-Becerril, D.U. and M.I. Tapia-Peña. - 1995. Planktonic diatoms from the Gulf of California and coasts off Baja California: species of the genus Thalassiosira. Bot. Mar., 38: 543-555.

Hernández-Becerril, D.U., E. Bravo-Sierra and Y. Ramírez-Valdéz. - 2001. Coccolithophorids from the west coast of Baja California, Mexico. Hydrobiologia, 452: 31-45.

Horner, R.A., B.M. Hickey and J.R. Postel - 2000. Pseudonitzschia blooms and physical oceanography off Washington State, USA. South Afr. J. Mar. Sci., 22: 299-308.

Lange, C.B., F.M.H. Reid and M. Vernet. - 1994. Temporal distribution of the potentially toxic diatom Pseudonitzschia australis at a coastal site in Southern California. Mar. Ecol. Progr. Ser., 104: 309-312.

Lange, C.B., A.L. Weinheimer, F.M.H. Reid, E. Tappa and R.C. Thunnel. - 2000. Response of siliceous microplankton from the Santa Barbara Basin to the 1997-98 El Niño event. Cal. Coop. Ocean. Fish. Inv. Rep., 41: 186-193.

Lavaniegos, B.E., L.C. Jiménez-Pérez and G. Gaxiola-Castro. 2002. Plankton response to El Niño 1997-1998 and La Niña 1999 in the southern region of the California Current. Progr. Oceanogr., 54: 33-58.

Lavaniegos, B.E., G. Gaxiola-Castro, L.C. Jiménez-Pérez, M.R. González-Esparza, T. Baumgartner and J. García-Córdoba. 2003. 1997-98 El Niño effect on the pelagic ecosystem of the California current off Baja California, Mexico. Geofísica Int., 42: 483-494

Lee, H.Y. and G.A. Fryxell. - 1996. Bicapitate Nitzschia species: Abundant nanoplankton in aggregates during NovemberDecember (1992) in the equatorial Pacific. J. Plankton Res., 18: 1271-1294.

Longhurst, A.R., C.J. Lorenzen and W.H. Thomas. - 1967. The role of pelagic crabs in the grazing of phytoplankton off Baja California. Ecology, 48: 190-200.
Lynn, R.J., T. Baumgartner, J. García, C.A. Collins, T.L. Hayward, K.D. Hyrenbach, A.W. Mantyla, T. Murpheree, A. Shankle, F.B. Schwing, K.M. Sakuma and M.J. Tegner. - 1998. The state of the California Current, 1997-1998: transition to El Niño conditions. Cal. Coop. Ocean. Fish. Inv. Rep., 39: 25-49.

Malone, T.C. - 1971. The relative importance of nannoplankton and netplankton as primary producers in the California Current system. Fish. Bull., 69: 799-820.

Meave del Castillo, M.E., J.A. Aké-Castillo and S. GuerraMartínez. - 2000. Dominancia de diatomeas del género Pseudonitzschia H. Peragallo en las costas de Baja California (Marzo 1999). Abstracts IX Congreso Nacional de Oceanografía. Huatulco, Oax., México, 22-26 May, 2000.

Medlin, L.K., G.L.A. Barker, M.E.M. Baumann, P.K. Hayes and M. Lange. - 1994. Molecular biology and systematics. In: J.C. Green and B.S.C. Leadbeater (eds.), The Haptophyte Algae, pp. 393-412. Claredon Press, Oxford.

Millán Núñez, E. and D.H. Loya Salinas. - 1993. Variación temporal del fitoplancton en una zona costera del noroeste de Baja California. Cienc. Mar., 19: 61-74.

Mullin, M.M. - 1998. Biomasses of large-celled phytoplankton and their relation to the nitracline and grazing in the California Current system off southern California, 1994-1996. Cal. Coop. Ocean. Fish. Inv. Rep., 39: 117-123.

Mullin, M.M. - 2000. Large-celled phytoplankton, the nitricline, and grazing during the California 1997-98 El Niño. Cal. Coop. Ocean. Fish. Inv. Rep., 41: 161-166.

Parrés Sierra, A., M. López and E.G. Pavía. - 1997. Oceanografía física del Océano Pacífico nororiental. In: Lavín, M.F. (ed.), Contribuciones a la Oceanografía Física en México. pp. 1-24. Unión Geofísica Mexicana Monographs 3, México.

Reid, F.M.H., E. Fuglister and J.B. Jordan. - 1970. Phytoplankton taxonomy and standing crop. In: Strickland, J.D.H. (ed.), The ecology of the plankton off La Jolla, California, in the period April through September, 1967, pp. 51-66. Bull. Scripps Inst. Oceanogr. 17, San Diego.

Smayda, T.J. - 1975. Net phytoplankton and the greater than 20 micron phytoplankton size fractions in upwelling waters off Baja California. Fish. Bull., 73: 38-50.

Trainer, V.L., N.G. Adams, B.D. Bill, C.M. Stehr, J.C. Wekell, P. Moeller, M. Busman and D. Woodruff. - 2000. Domoic acid production near California coastal upwelling zones, June 1998. Limnol. Oceanogr., 45: 1818-1833.

Trainer, V.L., N.G. Adams and J.C. Wekell - - 2001. Domoic-acid producing Pseudo-nitzschia species off the U.S. west coast associated with intoxication events. In: Hallegraeff, G.M., S.I. Blackburn, C.J. Bolch and R.J. Lewis (eds.), Harmful Algal Blooms Conference Proceedings. pp. 46-49. UNESCO, Paris.

Tyrell, T. and A. Merico. - 2004. Emiliania huxleyi: bloom observations and the conditions that induce them. In: Thierstein, H.R. and J.R. Young (eds.), Coccolithophores. From Molecular Processes to Global Impact. pp. 75-97. Springer-Verlag, Berlin.

Venrick, E.L. - 1998. Spring in the California Current: the distribution of phytoplankton species, April 1993 and April 1995. Mar. Ecol. Progr. Ser. 167: 73-88.

Wang, D.P. and J.J. Walsh. - 1976. Objetive analysis of the upwelling ecosystem off Baja California. J. Mar. Res., 34: 43-60.

Winter, A., M. Elbrächter and G. Krause. - 1999. Subtropical coccolithophorids in the Weddell Sea. Deep-Sea Res. I, 46: 439-449.

Young, J.R. and P. Westbroek, P. - 1991. Phenotypic variation in the coccolithophorid species Emiliania huxleyi. Mar. Micropaleontol., 18: 5-23.

Scient. ed.: L. Hutchings.

Received January 19, 2006. Accepted June 14, 2007.

Published online October 18, 2007. 